\title{
9. Mining the Mining Archives
}

\author{
Sachiyo Kanzaki
}

Sachiyo Kanzaki, PhD in Anthropology, is currently responsible for the Japanese language and culture programme at the Université du Québec à Montréal (UQAM). Through her research, she seeks to develop knowledge with an interdisciplinary approach.

kanzaki.sachiyo@uqam.ca

It was 2013, post triple-disaster in Fukushima. I chose my postdoctoral subject: the Japanese nuclear facilities and regional development. I make some phone calls, pack a bag and move to Saskatchewan for a year to work at the International Centre for Northern Governance and Development (ICNGD) at the Johnson Shoyama Graduate School of Public Policy. Since I had already worked on part of the Canadian mining industry (asbestos), I knew the Japanese nuclear industry could not exist without Canadian yellow cake, since Japan has no uranium mines. So, Saskatoon was undeniably the best place to access archives on the subject.

Indeed, in Canada, Saskatchewan was the best place to conduct my research. During World War II, Canada participated in the Manhattan project by providing refined uranium to U.S. facilities, though it was rather the uranium from the Shinkolobwe Mine in Belgian Congo that was used for the atomic bombing of Hiroshima and Nagasaki as it filled most of the requirements at the beginning of the project. ${ }^{1}$ During the Cold War, Saskatchewan became the major provider of uranium for Western countries, and Canada has been the largest exporter of uranium ore in the world until 2009, when Kazakhstan took the lead. It goes without saying that Canada has been Japan's largest uranium partner over a long period. 
However, as is the case for anyone working in the field of nuclear policy, it is not always easy to access all the necessary archives, for military and political reasons. In Japan, the Act on Access to Information Held by Administrative Organs only came into effect in 2001, but it was then followed by the Specially Designated Secrets Act (SDS) in 2013, allowing the government to restrict disclosure of sensitive information. This is why many researchers working on Japan rely on American-disclosed archives to study Japan's nuclear policy. Having limited time to undergo my postdoctoral research and considering the accessibility of archived documents, I had to carefully choose a topic based on feasibility in terms of collecting materials.

Before the Fukushima nuclear accident, with the assistance of the electricity companies, fifty-four operational nuclear reactors were installed in eighteen different power stations in Japan. Forty-four municipalities had nuclear power plants or related facilities. In the 1970s, most of them accepted these facilities described as "clean and innovative" in the hopes of developing their region. At the time, the Japanese government viewed their construction as another way of solving the country's unbalanced regional development. During the ten years preceding the beginning of operation of a nuclear power station, the host and surrounding municipalities received each year, through prefectural governments, grants of 44.9 billion yen (about five hundred million dollars), and after the construction, two billion yen (about twenty million dollars). The host municipalities were believed to be well-off thanks to these grants, subsidies and revenues from electric companies and fuel taxes, as long, of course, as there were no accidents causing loss of life or municipal ground, like in the case of Fukushima Daiichi. However, some of the host municipalities had financial difficulties even before the Fukushima 
accident, and this impact on regional development was the starting point of my postdoctoral research. Any reactor has an age limit, and no money will be given to the municipalities after twenty-five to forty-five years of operation. Therefore, they usually sought the installation of another reactor in their municipality in order to secure further funds. This cycle of dependency is problematic considering the use of the budget for "regional development." Sifting through the central government's archives, it became clear that the problem was rather caused by the fact that the construction period inflated the municipal budget enormously, and then reduced it dramatically once the reactors started to operate. However, ten years was enough to change the socioeconomic situation of a municipality, and it would become difficult to adjust later. The regional development grants were used for construction projects such as amusement parks, museums, onsen and even hotels. But there was a maintenance cost attached to these infrastructures that caused severe budgetary burdens for smaller municipalities. Since the money they received was for their "necessary development," it could not be accrued and had to be used during the same fiscal year. With changes to applicable laws in 2003, municipalities could use the "regional development" related funds to pay their employees and maintenance fees. However, by doing so, the municipalities became more dependent on the allocated funds from the central government. As such, today, almost any expense can be budgeted as a "regional development" expenditure. The focus during my fieldwork was the social impact of these policies.

During my fieldwork in Japan in 2014, I could easily reach most of the municipal budget-related information in the national archives. However, when looking at the social 
impact of the installation of nuclear facilities, at the local level, there was little information available at the National Diet Library. This was because the construction of nuclear facilities in rural areas began in the 1960s, and the national archives do not hold the old municipal publications, nor the small-scale citizens' publications. Therefore, it became necessary to visit the municipalities I was working on. The locations chosen to install nuclear power plants happened to be generally dependent on the farming and fishing industries, and had been suffering from rural exodus. In other words, the reactors were installed in the countryside, in remote regions, away from large cities. This explains why the Tokyo Electric Power Company (TEPCO) has no nuclear plants in its service area, but has one in Fukushima and another in Niigata where the local electricity is provided by Tohoku Electric Power. Some see this structure as sharing similarities with colonial exploitation models. It could also be compared to the situation in Canada, where some of the electricity produced is not used by its own population but for export purposes, and where yellow cake is produced in a province that doesn't have nuclear power stations.

As a postdoc, I had a chance to live in Saskatoon, in the heart of the Canadian uranium mining industry, where Cameco's headquarters are situated. At the airport, I was welcomed by a picture on the wall proudly explaining Saskatchewan's contribution to the nuclear industry and by a monument, the Blairmore Ring, in homage to Saskatchewan's potash miners. $^{2}$

My fieldwork in Saskatchewan wasn't easy. Not because of the accident that happened in Fukushima, but rather because, at the time, some northern Saskatchewan sites 
were chosen for nuclear (radioactive) waste management, raising the population's concerns around nuclear issues. As for uranium mining in Canada, to my surprise, there was not much in the archives at the time. I learned uranium mining nowadays is closely related to northern Indigenous communities, but there were not many documents in the archives on the subject either. The only way to find more information about the contemporary uranium industry was from the mining companies themselves. But even so, it was difficult to get my hands on actual uranium mining documents as they are considered trade secrets. Also, the inaccessibility of the sites limited my fieldwork. Fortunately, I could visit Pinehouse, a northernmost municipality of Saskatchewan, accessible by Highway 914 which is the only road that passes through the community. Pinehouse is the only established community along this road and uranium mines are accessible almost only by airplane. In addition, in the field in general, in Canada just like in Japan, the fact that I am a woman still capable of bearing children limited my access to these sites. In Japan, the masculine nature of this industrial sector limited even my ability to stay in a private hotel in a northern municipality that did not have rooms or toilets for women.

In Japan and in Canada, I couldn't help but notice some similarities. Perhaps the most obvious was location. The municipalities I visited in Japan were in remote northern regions. The largest city in the province, Saskatoon is higher up North compared to other major Canadian cities. That said it represents "the south" of the province, compared to the Northern Saskatchewan Administration District ${ }^{3}$ which encompasses the entire northern portion of the province starting roughly north of Prince Albert National Park (approximately forty-nine percent of the province). There are over forty communities, representing less than four percent of the 
province's population, ${ }^{4}$ with a high proportion of Indigenous people. Another similarity is in the socioeconomic impact. Both the uranium mines in Canada and the nuclear facilities in Japan became important local job providers. Traditionally, northern and northeast Japan has provided seasonal rank-and-file workers called dekasegi (literally, working away from home) to Tokyo and its surrounding factories, but the presence of nuclear facilities in these areas has reduced the number of dekasegi. There are also similarities on the social level. The Japanese communities have divided opinions on the presence of nuclear facilities, and Northern Saskatchewan communities have divided opinions on the nuclear waste management.

Uranium mining in northern Saskatchewan was nationalized in 1943 and the federal crown corporation Eldorado Mining and Refining Limited was created in 1944, later to be renamed Eldorado Nuclear Limited. This nationalization policy was lifted in 1948, after World War II, and mineral exploration to find new deposits in the Athabasca region came back in force. With the opening of several mines, the Saskatchewan government established a community, Uranium City, to service the uranium mines in the Beaverlodge area. The provincial government took the company town of Arvida in Quebec as a model town instead of keeping the small mining settlements separated. ${ }^{5}$ The population of Uranium City grew; at the time of the two-hour visit of Prince Philip during the Queen's tour in 1959, the mining community was already at 4,500 residents. I looked for recent information on Uranium City in the archives during my postdoc, but did not find much about it. I found more information on the private websites of former residents than at the university library. 
The access to Uranium City is usually only possible by airplane, or by Saskatchewan Highway 962 during the very limited time when the ice road opens over Lake Athabasca. Either way, access is not easy. Flights are not so frequent, and its one terminal airport, with no amenities such as shops or wireless internet, is ten kilometres away from the city. If you choose the ice road, you have to plan for gas, food and somewhere to sleep in a -30 degrees Celsius environment. The distance is approximately 824 kilometres by airplane and 1,237 kilometres by car. The city was closed in 1982 with the closure of the mines, and most residents left. There are many former residents of Uranium City in Saskatoon, so I could gather some further information. For those who were still children when they left, the closure of the city was unexpected. Having played an important role during the Cold War, and for the development of the domestically produced CANDU reactor, Uranium City's population declined suddenly with the shutdown of the mines announced at the end of 1981. Most of the population fled before the shutdown itself, not so long after the replacement of Uranium City High School by the newly built Candu High School in 1978.

Before this happened, in 1968, there was a major uranium discovery at Rabbit Lake on the eastern rim of the Athabasca Basin. The mine, opened in 1975, became the longest uranium producing operation in the province until suspending its activities in 2016 . It had been operated by Cameco, a merger of the crown corporations Eldorado Nuclear and Saskatchewan Mining Development Corporation. Cameco started the McArthur River/Key Lake operation and opened the Cigar Lake Mine on the same side of the Athabasca Basin where some other uranium mining projects were on the way, such as the McClean Lake Mill. 
In the meantime, a new mining model had appeared in Canada. Because of the advancements in technologies related to mining and the environmental and cost issues, there were no new mining "towns" established after $1970 .{ }^{6}$ Before this shift, the opening of a mine meant the creation of a community that develops, over time, a local market and various installations to provide the community with goods and public services. However, such a community ran the risk of meeting the same fate as Uranium City. To avoid such outcomes, miners now periodically commute by plane from nearby communities.

Today, hiring from nearby communities implies an increase in Indigenous labour in the uranium mines of Saskatchewan. In addition, because of the land and resource claims from the Indigenous communities and the importance of local employment, more and more Indigenous people are encouraged to work in these mines. Indigenous communities have been ignored in negotiations on natural resources exploration for a long time. The federal government began to show recognition for Indigenous land claims in 1973, following the Supreme Court's decision in the Calder case. Specific land and resource claims have been progressing since the 1990s. Projects related to natural resources, such as mining, now require a tripartite cooperation; the mining company and the government have to establish a partnership with Indigenous communities. Therefore, many aspects of today's uranium mining industry differ from the days of Uranium City.

In the Northern Saskatchewan narrative, mining became a part of life. Job creation is crucial in the region, and mining creates a significant number of jobs for the remote Indigenous communities. Even though the new fly-in fly-out system requires a particular lifestyle, the 
northern population rather value the opportunity to work. Ironically, a part of the workforce committed to this "three weeks in a mine, two weeks at home" way of life already experienced Canada's notorious residential school system. So, the increase in employment is seen as positive, but it is mostly at the entry-level positions ${ }^{7}$ in the mining companies, far from the headquarters situated in big cities. And so, in the global energy supply chain, even though nuclear technology is considered a high-tech industry for both the northern Saskatchewan yellow cake and the Japanese coastal town activities, similar issues are raised in these communities given the structural "centre vs. periphery" nature of these industries.

During this workshop, in addition to discovering the work of Marissa Bell edited by Laurel MacDowell, ${ }^{8}$ I was delighted to learn that there is recent work done on Uranium City by Robert Boschman and Bill Bunn, ${ }^{9}$ and that an archivist in Ottawa recently acquired documents from Eldorado Nuclear that could prove to be a veritable treasure trove. ${ }^{10}$ Since Canada's nuclear history began with the discovery of its uranium, archives on its mining could be a significant contribution to research on the subject.

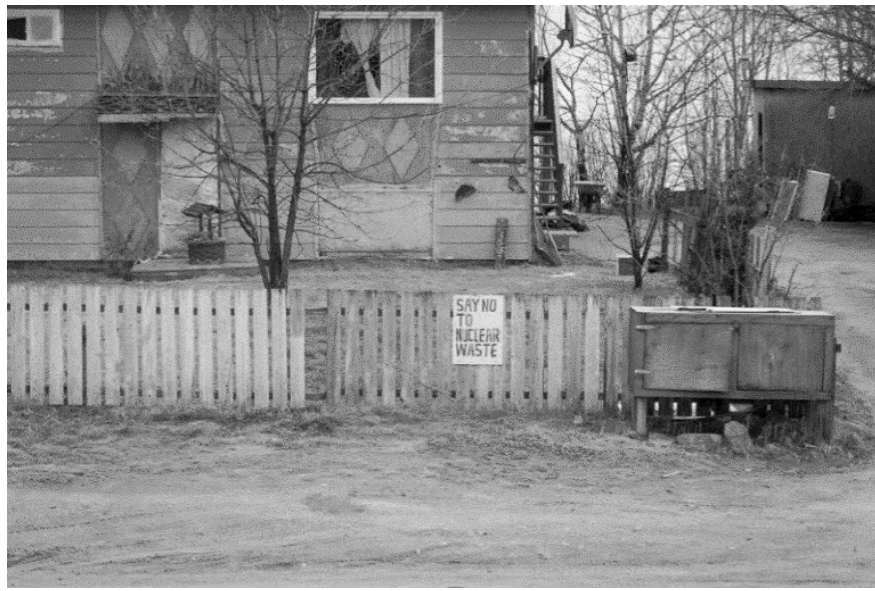

Figure 7. Pinehouse Saskatchewan, July 2014, photo taken by the author (S. Kanzaki).

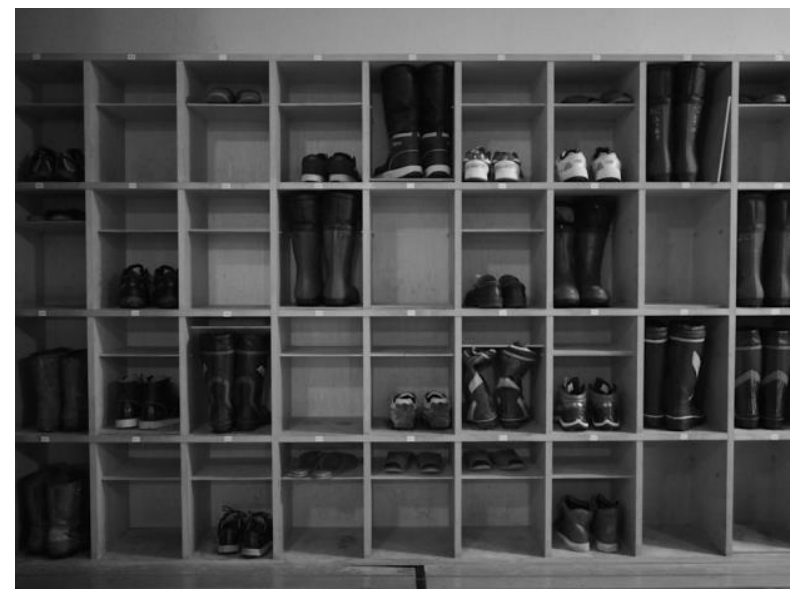

Figure 8. Rokkasho Japan, February 2014, photo taken by the author (S. Kanzaki). 
A humble protest sign (left) in Pinehouse, the northernmost village of Saskatchewan of 1,000 residents. With no nuclear power in the province, northern Saskatchewan has continued to provide yellow cake to Canada and other countries, including Japan which has no uranium mines on its soil. Resource extraction has been related to Canada's colonial history, and nowadays, the Indigenous communities are targeted for nuclear waste management sites. At the other end of the uranium industry, the village of Rokkasho in the northernmost part of Japan's main island of Honshu receives radioactive waste from all over Japan to its nuclear fuel reprocessing facility that is still under construction after more than three decades. The entrance of the local hotel is filled with workers' rubber boots and work shoes (right), contrasting with the promoted clean and innovative image of nuclear technology.

${ }^{1}$ WDG Hunter, "The Development of the Canadian Uranium Industry: An Experiment in Public Enterprise," The Canadian Journal of Economics and Political Science / Revue Canadienne D'Économique et de Science Politique 28, no. 3 (1962): 329-52.

${ }^{2}$ This monument was no longer there in 2019.

${ }^{3}$ Northern Saskatchewan as an entire physical area.

4 Government of Saskatchewan, "Northern Saskatchewan Administrative District," accessed November 30, 2020, https://www.saskatchewan.ca/business/first-nations-metis-andnorthern-community-businesses/economic-development/northern-administration-district

${ }^{5}$ Graham F. Parsons, and Ron Barsi, "Uranium Mining in Northern Saskatchewan: A Public-Private Transition," in Large Mines and the Community: Socioeconomic and Environmental Effects in Latin America, Canada and Spain, eds. Gary McMahon and Felix Remy (Ottawa: IDRC, 2001).

${ }^{6}$ Archibald RM Ritter, “Canada: From Fly-In, Fly-Out to Mining Metropolis," in Gary McMahon and Felix Remy (eds.) in Large Mines and the Community: Socioeconomic and Environmental Effects in Latin America, Canada and Spain, eds. Gary McMahon and Felix Remy (Ottawa: IDRC, 2001).

7 Bethany Haalboom, "Confronting Risk: A Case Study of Aboriginal Peoples' Participation in Environmental Governance of Uranium Mining, Saskatchewan," The Canadian Geographer / Le Géographe Canadien 58, no. 3 (2014): 238-273.

${ }^{8}$ David E Bell, and Marissa Z Bell, "Port Hope Burning: The trail of Eldorado, the Uranium Medical Research Center, and Community Tension over Scientific Uncertainty," in Nuclear 
Portraits: Communities, the Environment, and Public Policy, eds. Laurel Sefton MacDowell (Toronto: University of Toronto Press, 2017), 274-311.

${ }^{9}$ Robert Boschman, and Bill Bunn, "Nuclear Avenue: 'Cyclonic Development,' Abandonment, and Relations in Uranium City, Canada," Humanities 7 no. 1 (2018).

${ }^{10}$ Library and Archives Canada, Eldorado Nuclear Limited, fonds [multiple media] 19271982. RG134 (Item ID number: 393). 